\title{
THE FUNCTIONS OF WORD DUPLICATION IN INDONESIAN LANGUAGES.
}

\section{Surnmary}

In this peper, which is not intended to give an exhaustive collection of word-types, the author tries to review and to systematize a number of the most characteristic meanings of duplication (and reduplication) in Indonesian languages and to look more closely into some aspects of these processes which have not yet reteived adequate attention.

"Nothing is more natural than the prevalence of reduplication, in other words, the repetition of all or part of the radical element", Sapir rightly observes ${ }^{1}$ ). So, when Gray ${ }^{2}$ ) seemingly held that 'iterative compounds' are relaivively rare, "though one may cite such examples as .... Sanskrit untarottara- "highe!" (and) higher", páñca-pañca "five each" and English goody-goody", he probably forgot that he had selected his examples from literary languages. In 'more advanced stages of civilization', among groups and classes which have, generally speaking, lost contact with "primitiveaess', although it is always apt to come to the surface, in circles where the so-called intellectual or modern mental structure is dominating, reduplicating and iterative devices are a rather unimportant part of language. Readers of many a book on general linguistics might, however, be led astray by such statiments as: "in Malay the plural is formed by repeating the singular" "), "in Indonesian langu iges reduplication constitutes a regular grammatical process" 4), "word-duplication is one of the general characteristics of the Melanesian (so, not of the Indonesian?) group of languages" etc.

1) E. Sapir, Language, 1921, p. 79.

2) L. H. Gray, Foundations of Language, 1939, p. 164.

3) Cp. Gray, p. 180; W. L. Graff, Language and languages, 1932, p. 155; H. Guntert, Uber Reirawortbildungen, 1914, p. 182. The few remarks by G. Ferrand, in A. MeilletM. Cohen, Les langues du monde, 1924, p. 432 are afijlảing but exhaustive.

4) Graff, o.c., p. 154; cf. p. 424. 
Although I am not the first to write on this subject ${ }^{5}$ ), it might (א.rhaps be of use to point out some common misunderstandings with regard to word-duplication in $\mathrm{IN}$ languages, to review a number of its cost characteristic examples and to look a little more closely into some aspects of the phenomenon which have not received, as far as I can judge, aclequate attention. Our remarks will chiefly be confined to duplication (the repetition of the complete word) as a process in word-formation, but it will often be inevitable to discuss also instances of redur'ication (which consists in the repetition of part of the word, usually at the beginning, but sometimes at the end) and other aspects of the phenomenon. It is very often absolutely impossible to distinguish reduplication from complete gemination ${ }^{5}$ a), in the first place, because from the formal point of view there is no hard-and-íast line: often a geminated and a reduplicated form occur in the same language or dialect without any difference in meaning: Mal. puyu $u^{2}$ (i.e. puyu-puyu) $=$ pépuyu "climbing perch", labu ${ }^{2}=$ lělabu "pipkin", or one language has a reduplicated form for the same thing which a closely related idiom denotes by repeating a word-base: Mad. nin-konan "firefly", but in the Isle of Java and in Malay we find kona $\dot{n}^{2}$; moreover there are such forms as O.Jav. a-wěrě-wěrö "to be continually drunk" and wěrě-wěrěh "fiancé(e)" which rather constitute a variety of duplication than reduplicated forms; in Bima dissyllabic words are repeated in their entirety, polysyllabic words only in part (tampuu-mpun "to begin"). And from the functional point of view the two types are often nearly or even quite indistinguishable from each other, although there are interesting exceptions (e.g. in the language of Roti). Besides, it is not possible to draw a hard-and-fast line between duplication as a process in word-formation and 'syntactical' duplication.

There is still another preliminary remark to be made. It cannot be said that the duplicative process is of the same significance in all IN languages. Whereas in the written Malay of the classical texts it is used, with regard

5) See especially A. F. Pott, Doppelung, als eines der wichtigsten Bindungsmittel der Sprache, 1862 and R. Eirandstetter, Die Reduplikation in der indianischen, indoresischen und indogerman'schen Sprachen, 1917. Pott, however, had at his disposal not more than scanty and scmetimes defective IN material. Brandstetter has also dealt with reduplication etc. as a method to form base-words; he emphasizes the formal poin: of view. F. R. Blake has studied reduplication in Tagalog: his detailed paper appeared in American Journal of Plillology, 38 (152), 1917. A more circumstantial publication on the same subject, C. Lopez, Reduplication in Tagalog, Publ. Inst. Nat. Language, VII, Maniia 1941, gives a description of all (408!) form classes in which duplication and reduplication play a part. The book has been arranged after the formal point of view.

5a) To avoild using too often the term 'duplication', in this paper iteration = geminaltion $=$ doubling $=$ duplication, 
to substantives, mainly to express diversity (anak "child": anak "various children") and in a rather limited number of words to denote likeness (lanit "sky": lanit" "cloth canopy or palate of the mouth"), the dialects of the Straits reveal to us the existence of many more duplicated words denoting small animals, plants, eatables and drinkables, parts of technical constructions etc., which to all probability do not, as a formation, belong to recent times only $\left.{ }^{6}\right)$. In the Batak languages, where complete duplication is of great importance, reduplication is, comparatively speaking, seldom found. Whereas, in Bima, without being rare, word-duplication has rather limited functions (according to Jonker ${ }^{7}$ ) it does not derive substantives from verbal words by doubling the base, a process which is fairly often applied in Buginese and Macassar), in the language of Roti it is, like partial repetition, a frequent and complex phenomenon ${ }^{8}$ ). And we must turn to Philippine and Celebes languages for finding reduplication as a regular process in word-formation: Tag. sulat "a writing": susulat "one who will write", tawa "a laugh": tatawa "one who will laugh"; this form, in its turn, underlies a derivative with the infix -um-: tumatawa "one who is laughing" etc. We have cleliberately refrained from entering into particulars concerning combinations of duplication and reduplication with suffixes.

It has long since been recognized that sound-imitation is at the root of many a double or reduplicative form ${ }^{9}$ ). The imitative or onomatopoeic words formed by these processes, denote in the first place a sound (Jap. karakara of a rattling sound; O.Ind. ululi-, ulülu-, Lat. ululätus, uluāabilis, Eng. chugchug) or an animal (Lat. upupa "hoopoe"; Lat. cuculus, Dutch koekoek, Eng. cuckoo; Chinook iqoë'lqoêl "owl") or an object (Skt. dundubhi-"drum"; gargara-"whirlpool") which gives out a sound. The doubling of the base in these nouns (beside which singie base-words do not occur) may be merely imitative (Dutch koekoek) and, in other cases, interpreted as meaning that the sound is uttered habitually by the animal or object designated. There are very numerous IN examples: ${ }^{10}$ ) Mal. ciap" "wood.

\footnotetext{
9) See also *. G. Emeis, Inleiding tot de Bahasa Indonésia, 2d ed. 1948, ch. XLIX.

7 J. C. G. Jonker, Bimaneesche Spraakkkunst, 1896, p. 218.

8) See J. C. G. Jonker, Rottineesche Spraakkuist, 1915, p. 178-213.

9) See, e.g., K. Brugmann, Kurze vergleichende Grammatik der idg. Sprachen, 1903, p. 286.

10) Cp. also my paper "Some remarks on onomatopoeia, sound-symbolism and wordformation a propos of the theories of C. N. Maxwell', Tijdschrift voor Indische TaalLand-en Volkenkunde 80 (1940), p. 134 , esp. p. 185 ff.
} 
quail", tetuhu "owl" (I do not mention such instances is bebek "duck", which constitutes a word-base constructed upon the repeated sound of the quacking uek-uek); tuan' "a sort of bamboo-horn used for signalling"; Oirata (Kisar) mau "cat"; Bar. paa ${ }^{2}$ or kao " "crow"; ree " "bambooharp" (ree denotes the sound of rattling bamboo lathes); geso" "violin"; Mal. kĕlonkah-lonkah "the sound of loose planking straining in a ship in heavy weather"; Min. lapak', lapok" "a sound like the smacking of lips, the sound of people eating". There are, of course, also adjectival words: Mal. lěk $a n^{2}$ "changing along, e.g. of a ploughshare", and verbs, like Jav. uwèg" "chatter (of ducks)" When onomatopoeic duplicatives are used as verbs, doubling of the base generally denotes repetition: Mac. moko "to grumble; a watch", cp. Hindi phusa-phusānä "to whisper" etc. Like Indians Indonesians seem to possess a genius for creating such tirms. Moreover, there are many words in which things or events which do not involve a sound in themselves, are indicated by a combination of sounds which seems to have been formed after the outward appearance of the object or event (Lautbilder') "1) (cp. Hindi camacamānā "to glitter"; the Latir "Inot expressif" querquera "ague"): Mal. kilauªn "flooded with light; brightness", bĕr-kilau" "øo glitter"; Hova wihi" "to tremble". Compare also such names of animals as Mal. kupu", Nias kawa ${ }^{2}$ etc. "but erfly" (Lat. papilio, OHGerm. fifalter, Chinook seqlalolö etc.), which clearly are of an 'analogica" character: the sound of the word corresponds in some way or other with the movements of the animal or with the impression made by it on the spectator. But in IN languages the very frequent doubled and reduplicated words denote also other animals, trees, plants, tools, utensils, dishes, tit-bits, bodily infirmities, parts of ships, houses and other constructed objects, parts of the body and, moreover, such persons and objects as a clown, a prostitute, a scare-crow, a wicked spirit, dregs, last spark of a fire etc. ${ }^{12}$ ): Mal. laba ${ }^{2}$ (dial. also lellaba "spider"; kura "tortoise", many birds and fishes: bian" "herring", para $\dot{n}^{2}$ etc.; Sasak běbo inkol "crocodile"; Mal. lada "a certain plant"; manun "a certain herb"; sibar "border (to embroid"ry)"; panji ${ }^{2}$ "pennon"; ali "sling"; Jav. ani " "harvesting-knife"; Sas. jějěrnku "knee"; Mal. (Batavia etc.) opak "a kind of pancake". Solnetimes it will be possible to venture a suggestion about the "origin' of the word: Sas. jëjarin "spider" is clearly derived from jarin "net" (the animal which makes webs or the

11) 1 refer to my 'Remarks', p. $164 \mathrm{ff}$.

12) See also $\mathcal{L}$. Tcbler, Uber die Wortzusammensetzung (Gerlin 1866), p. 9. 
animal relating to a web), the Malay term pisañ includes a number of wild anonaceous plants which suggest the pisan "banana" in some way ${ }^{13}$ ). The ikan laya ${ }^{2}$ (Mal.) "flying fish" is called after its most obvious characteristic: layan "being borne through the air" 14). In general the groups of ideas mentioned form part of the vocabulary of the general public, nay of simple folk, for whom they possess a certain emotional value. In Nias, Malay etc. the names of animals belonging to this type especially apply to small birds, insects and lower living beings. As to the categories of nouns formed in this way there is a striking resemblance between unrelated languages, e.g. between Malay and Chinook ${ }^{15}$ ) (birds and other animals, plants, parts of the body, terms of relationship), and in the ancient IE word-formation reduplication is found almost exclusively in imitative, emotional, expressive or technical words ${ }^{16}$ ). Many names of animals and plants in the ancient IE languages are formed like Lat. sisarra "a kind of

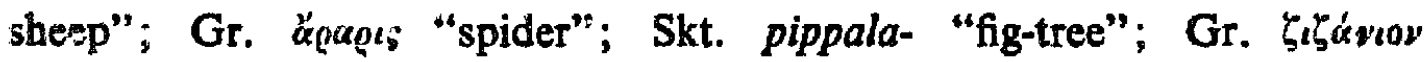
"Weeds"; riyidov; Lat. papaver; jujuba; lilium etc. Compare in the speech of the lower classes: French (Paris) digue-digue "état de malaise"; gnognotte "chose de mauvaise qualité"; pépère "homme tranquille et bon" etc. As to the words for evil spirits, ghosts etc. (e.g. Mal. longa"; hantu aru ${ }^{2}$; Min. si nian $^{2}$; cp. such animals' names as, in Banggai fairytales, i Bababui "the Hog": babul "hog") I would refer to Grigri (a dwarf); pincess Mikomikonia; King Bambo; Titurel; Durandarte and other emotivefantistical European names.

In . wursery speech, fairy tales etc. duplication often results in instrumental nouns. Dutch tuf-tuf "motorcar"; Germ. Stich" "needle", Klopf" "hamner" ${ }^{17}$ ), and in the ancient IE languages, e.g. in Hittite where'reduplication is f irly conmon, we may list not only musical instruments, but also Hitt. hal haras "a tind of vessel"; Lat. cuc(c)uma "kettle"; Gr. yiyy "hinge". In Polynesian languages, e.g. in the Duke of York Island, we

1.) See below, p. $190 \mathrm{~s}$.

ii) See also N. Adriani, Spraakkunst der Bare'e-Taal, Bandoeng 1931, p. 117.

13) : refer io F. Boas, Chinouk, Handbook of American Indian Langliages, I, 1911, ค. 0.55 i.

19) I refer to Lingua, I, p. 96 f.; see also H. Paul, Prinzipien der Sprachyeschichte, \$127.

17) Many example: are given by $G$. Gerland, Intensiva und Iterativa, 1869, p. $110 \mathrm{ff}$. Other references can be fo und in my paper 'Opmerkingen over de toepassing der comparatieve methode op de Indonesische talen, voornamelijk in verband met hun woordstructudur', Bijdragen tot de Taai-, Land- en Voikenkundt van Nederlarasch-Indie,, 99, p. $39 i-466$. 
find kllktl "a spade": kill "to dig"; akak "a hammer": aki "to break" 16). In many languages of Celebes and the Philippine Islands these reduplirated names for tools and implements constitute a regular formation: compare, in Sangirese: sasile "a kind of fishing-net": sile "to fish", in Tontemboan (N. Celebes) where all reduplicated forms denote instruments: gogorit "saw": ma-gorit "to saw"; in these languages we sometimes find reduplicated words of this class which originally were dissyllabic: Sang. darahun (i.e. "dadahun) "needle": Mal. etc. jarum, Bisaya etr. dagom ${ }^{19}$ ). Although it is not a common device in the languages of the western Archipelago, we find some cases in Malay: (Penang) ocok" "a rattle or sistrum for driving or attracting fish": acok "inciting by words"; (Batavia) lou "a cylinder for holding sugar"; Batak somba "what serves as a means to ingratiate oneself"; cp. Mal. etc. sémbah "a gesture of worship"; Jav. aliñ "a screen" (the simple base is now out of use, but cp. O.Jav. kalin (= kanalin) "covered, hidden"); ulëg" "rubber". In Madurese this type is frequent: posapo (in this language the reduplicative syllabe is repeated after the base) "broom"; kolpokol "tongue of a bell": pokol "to knock, to strike". Similarly in the language of Mentaway (west of Sumatra) ${ }^{20}$ ), where reduplicated forms designate instruments (gugujut "match": gujut "to strike, rub, scrape against"), doubled words, however, are rather used to express an object which may serve as a moans or implement: oilk" "a ring for hanging something". In many cases words of this group probable belong to the 'primitive, emotive (in German: affektisch) or popular" terms discussed above, but a survey of the material shows that a large number of them must have their origin in a very frequent function of doubling and reduplication, viz. to express iterative and frequentaive aspects, customary action efc. In the language of Banggai (east of Celebes) ${ }^{21}$ ) a tool or instrument is designated by a reduplicative form, when it is the usual thing to perform an action, a word derived with a prefix primarily denotes an object which may (or can) be used to do so ${ }^{22}$ ). To many words these formative processes have, of course, extended analogically.

18) G. Brown and B. Danks, Dictionary and Grammar of the Dilke of York Jstand Language, p. $5 \mathrm{f}$, quoted by Graff, o.s., p. 155.

19) See also N. Adriani, Sangireesche Spraakkunst, p. 67.

20) As to this interesting fact see Adriani, Spraakkunstige schets van de Taal der Mentawai-eilanden, Bijdragen tot de Taal-, Land-en Volk. v. N.Indië, 84, p. 40 :

21) For the Banggai material I am most indebted to Father $f$. D. Van den Bergh.

2.2) According to J. A. T. Schwarz-N. Adriani, Hoofdstukken uit de Spraakkunst van het Tontemboansch, 1908, p. 56 in all these words reduplication is (from a historical point of view) a shorter form of complete gemination. This is, however, still an open question. 
Another basis function of the processes under discussion consists in denoting repetition, reiteration, frequence etc. In correlation with a series of similar or almost similar impressions a repeated word can be apt to convey the ideas of repeticion or frequency ${ }^{24}$ ). There is, however, no reason why we should adhere to Cassirer's opinion, who holds that "die Verdoppelung des Lautes oder der Silbe lediglich dazu bestimmt scheint, gewisse objektive Beschaffenhiten an dem bezeichneten Ding oder Vorgang in möglichster Treue wiederzugeben" ${ }^{25}$ ). However important, this "analogical' function is, to my mind, not the only root of all the meanings of these forms. As is well known a gemination can express repetition of action:

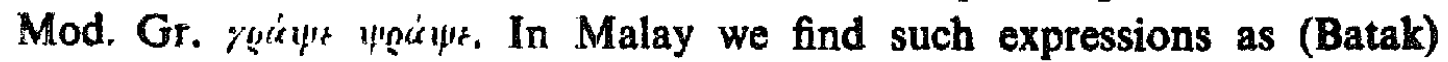
ogel" "to wag (of a dog's tail)"; lancain" "to go ricocheting along"; a certain number of stems occur in duplicated forms only, probably on account of the idea expressed: těr-sědu" "sobbing"; in Mori (Celebes) mé-lonso" "to leap repeatedly"; in Sangirese manianempain "to break to many pieces": manempan "to break" 26). Cp. in Takolma (Oregon) s"wilis"wal- "tear to pieces"; Haida la qi' ñgA ñgAin "he looks many times"; Skt. lunihi lunïhīti lunäti "cut cut" he cuts", i.e. "he cuts and cuts rgain". But compare also such instances as Toba Bat.: they went to forests and jungles monani $i^{2}$ sowara "everywherc to listen to the voice".

The iterative idea may imply distribution. Distributive plurality is often indicated by duplication. Repetition of a noun may express the occurrence of an event or an object here and there ${ }^{27}$ ) or at several times. Hence it is a widespread device in words denoting time or place: Maidu paka'nkanto "springs (distr.)": paka'ni "spring"; Ungar. ottan" "in places"; Skt. ahanyahuni "every day"; māsam māsam dehi "give every man a bean"; Hindi ban-ban märe phire "they wandered about in forest after forest"; Avestan nmāne-nmāne "in every house"; Lat. locis et locis; Roum. simbata simbata "every Saturday". In Tagalog and related languages "every" in expressions denoting time is indicated by gamination: tcontaón "every year"; cp. also Tont wën $i^{2}$ "every cvenin "; Manggarai leso "every day"; Mal.

23) H. Costenoble, Die Chamoro Sprache, The Hague 1940, p. 143

24) See also E. Hofmann, Ausdruckverstärkung, 1930, ch. I.

25) E. Cassirer, Philosophie der symbolischen Formen, 1, 1923, p. 143. With regard to reduplication Sapir (o.c., p. 81) expresses himself as follows: "the basic notion, at least in origin, is nearly always one of repetition or continuance".

26) Not al! examples given by Adriani, Sangireesche Spraakkunst, p. 197 are really 'frequentative".

27) Cp. the Skt. etān grāmān etān grämān "these villages here those villages there". This distributive gemination is 'volkstumlich' and 'umgangssprachlich'. 
sthari" "daily". The distributive force is quite obvious in numerals: when, in Nepali, one wants to say: "give these people three things (between them)" the numeral is put once, when, however, "give them three things each" is meant, it is expressed twice. In the Hindi sentence "in every house ten or twelve people are lying ill" the words house, ten and twelve are used twice. Similarly, in various other languages. In Tagalog etc. distributive numerals, indicating "so many each, so many apiece" are, from the fifth upward, reduplicate forms; the numeral adverbs may be reduplicated in a similar way. In Tont. the prefix ma- + an iterated numeral means: "two and two, two together etc."; similarly, a preixless numeral in Bare ${ }^{28}$ ), where, moreover, the distributive force is quite obvious: $r i$ at ${ }^{2}$ nya "by hundreds". Cp. also Ment. pa-pulu" "ten each"; Nias dua "two each". The indeterminate-distributive meaning (Skt. purusah purusah mi. dhanam upaiti "every man is mortal") can be perceived clearly in Bol. M. poriko'monag lango-lango "cut it to pieces, let every fragment be long!" Cp. also Mal. masin in "each": masin "separately, singly"; Gajo masin" or mémasin "each (separctely)"; Jav. ijèn" "one by one"; Busang lim "all": lim-lim "sundry"; Ng. Day. gîlā gìlā "alle, ein jeder dumm" "29); Bol. M. $k o$ onda" $k a$ "everywhere": onda "where?". Similarly, the indefinite force of Hitt. kwis may be made explicit by doubling: $\vec{k} w i s ~ k w i s$ " = Lat. quisquis. Cp. Mal. mana "where, which": dimana-mana "ever "where".

We are sometimes obliged to repeat an action, because we wo not succeed at first, hence 'iteration' may develop into 'trying": Toba Bat ajar ${ }^{2} i$ aki "try to instruct ne".

Although the idea of plurality is closely associated with that of distribution, the process:s under discussion express rather the existence of different kinds of a particular object than plurality. Generally speaking, they do not form trie plurals. Examples: Yami toko-tokon "various mountains"; awa-awan "inany years"; Tag. bagay-bagay "things of different kinds" (cp. also the so-called plural of the interrogative pronoun sino "who?": sino-sino); Tont. watu "various stones"; wale" "houses of all sorts"; an koso-koso" "in any valley" " springs of a rivule." (bulu-buludanēa means "where are various mountains $>$ mountain-range"); Bangga: ko paii" "children (including boys and girls,

28) Adriani, Spraakkunst der Bare'e-taal, p. 121 has not formulated this point in a sutisfactory way.

29) See A. Hardeland, Versuch einer Grammatik der Dajackschen Sprache, 1858, p. 67.

30) "Meervoud met verscheidenheid" (Schwarz-Adriani, o.c., p. 46). 
younger children and adolescents)", bulu-bulun "any kind of weeds" 31). Thus, we find in classical Malay ompan' "miscellaneous articles carried about by a trader or a travelior for use as gifts"; wain bër-lambak "money in little piles" (distribułion!): lambak "pile, heap"; berr-lapis" "lying in many layers": lapis "layer"; buro ${ }^{2}$ "various birds, birds of all sorts": buron "bird"; bijit-an "seeds of all sorts": biji "seed". Such expressions as ompain"; Sasak ala? "id."; andan "a kind of offering"; aroin" "horseraces" are always duplicatives, although single terms from which they are derived, may have existed. It may not be said that this function of duplication regularly or even clearly developed in all IN languages. In Rot, e.g., geminated substantives are, generally speaking, seldom used, with the exception of a phras with mesan "only, nothing but" (see p. 187). In. Mentaway, forms like biou ?t "furniture" are rare. In classical Malay we find them only in part of the cases where we might expect them on the authority of certain granmars. In Bare'e ${ }^{32}$ ), where doubling and reduplication always convey a particular meaning, it is, roughly speaking, not ever possible to repeat or to reduplicate a substantive in order to denote a large number of objects of the same kind etc. There are interesting parallels in other languages: Päli phalā-phala-means "various kinds of fruits": phala- "fruit" 33); Jap. samazama "various kinds". The idea of variety or diversity may predominate to such an extent that words like Ach. rupa (: rupa "form") and Mal. macam (: macam "kind") have come to be used as adjectives (Ach. mönökat rupa "merchandise of all kinds", (Bazaar-Malay) macam "of all surts, miscellaneous") to express the meaning of our "various".

It is sot easy to say how far certain grammars are right in stating that in some IN language or uther duplication is used to express a real plural. The puint did perhaps not always come under the notice of the authors. According to Father Arndt ${ }^{34}$ ) the subsiantive is spoken twice, when "es klar ausgedrückt werden soll, dass eine Mehrzahl von Personen oder Dingen gemeint ist", but his preceding remarks: "Besondere Formen für den Numerus .... gibt es nicht. Ist es aus dem Zusammenhange klar, ob es sich um (notional) Singular oder Plural handelt, dann bedarf sich

31) "Plural of kinds" (Father Van don Bergh).

32) See Afriani, Spraakkunst der Bare'e-taal, p. $11 \%$

38) On the origin of this type of compound which hws been disputed and probably is not the same in all cases, see W. Geiger, Pali, Strassburg 1916, $\$ 33$ (with references).

34) P. P. Amdt, Grammátik der Ngad'a-Sprache, Bädoeng 1933, p. 6. 
das Substantiv (as in IN languages in general) keiries Zusatzes" make us believe that regarding this point Ngad'a (Island of Flores) does not essentially differ from the above-mentioned languages. A similar remark may be made about the Oirata 'plural' ${ }^{35}$ ): in this language, spoken on the Island of Kisar, any substantive, it is taught, may be reduplicated in the plural, but this method is not poprular ${ }_{4}$ From some remarks by Costenoble ${ }^{36}$ ) it is sufficiently clear that in Chamoro reduplication is only used with a few words to express plurality: haga "daughter": hahäga (and other terms for persons and relationship). And in Bimanese duplication primarily expresses difference, variety and indefinite plurality: sanaji-naji means "princes of various rank and station". In Iloko, Williarns ${ }^{36 a}$ ) says, the plural is (in contradistinction from Ibanag and Pangasinan; often expressed in this way: puspuso "hearts": puso, but he says nothing about the use of these forms. As to Mori (Celebes), the late lamented author of the grammar, Dr. Esser ${ }^{37}$ ), even says that, one originally indefinite (and now perhaps collective) term excepted, any repetition of a substantive to express plurality must be regarded as a "detestable malayism".

During the XXth century the Malay language has, in fact, extended this use of duplicated nouns and they have, moreover, gradually assumed a purely plural meaning. Several authors make use of doubled nouns nearly always when English or Dutch would have a plural form: Walaupun hari masih pagi, tětapi disana tělah hampir pènuh dënan ora ¿n $^{2} \ldots$ Sekalian tëmpat dibawah ${ }^{2}$ pohon kayu, dipingir ${ }^{2}$ taman dan kolum, diatais gunun ${ }^{2}$ batu, dipintu ${ }^{2}$ gua, télah bérisi "although it was early in the day yet, that place was all but packed with people $\left(\operatorname{orain}^{2}\right)$... Everywhere under the trees, on the borders (pingir ${ }^{2}$ ) of the garden(s) and pond(s) on the rocks (gunun $\left.{ }^{2}\right)$, at the entrances (pintu ${ }^{2}$ ) to the caves, everywhere there was a crowd". We often find part of the worc's concerned doubled, the other part single, perhaps in some degree for rhythmical and euphonical reasons. Although it may be assumed as certain that the Dutch plural has influenced this development, it would not appear superfiuous to examine its history in every particular. Wheress, to mention only this, in classical Malay woros for limbs of the body and other uniform objects did not suffer duplication,

39) J. P. B. de Josseling de Jong, Studies in Indonesian culture, I, Amsterdam 1937, p. 192.

36) Costenoble, o.a., p. 142 f. and 463.

36a) H. W. Williams, Grammatische Skizze der Ilocano-Sprache, Diss. Munchen 1904, p. $11 \mathrm{fi}$.

37) S. J. Esser, Klank-en vormleer van het Morisch, 1, 1927, p. 73. 
it is now possible to write, e.g., daun ${ }^{2}$ telinanya "her ear-lobses". It would be an interesting task to investigate, how far there is a relation between speech and culture with regard to this point and how far the modernization of life may have played a part in the development. There is a very interesting parallel in Indian languages, where reduplication not only expresses continuation and repetition of action, but also severalty, totality and distributive plurality. Compare also in Aztec (Mexico) intchan oyakê "they went into their house" (all having one house only), but intchatchan oyayakê "they went into their several houses" (every man enteriig his own). In Klamath, where, according to Gatschet's hypcthesis ${ }^{38}$ ), the iden of repetition or iteration has been applied to space, surface, intensity, time and other categories, repetition of words also serves the purpose of expressing severalty or distribution, in $\operatorname{Coos}^{39}$ ) distributive plurality, indicated by reduplication or by suffixes, occurs very often. But the idea of plurality is little developed and when it occurs in Klamath, this is due to the fact that in a particular case severalty aid plurality coincide. In Kwakiutl, however, Boas ${ }^{40}$ ) remarked about 40 years ago, reduplication gradually assumed a purely plural significance, and the $A$ merican scholar added that in many cases in which it was thus applied in tis texts, the older generation criticized its use as inaccurate. The Japanese forms made by duplication may not properly be termed plurals, although yama ${ }^{2}$ means "mountains": they do not admit of numerals, convey the connotation of variety and cannot be derived from any single word ${ }^{41}$ ). In colloquial Persian duplication is very usual: murgh-murghä denotes a very large number of birds ${ }^{42}$ ).

Passing mention may be made of a language which seemingly does not distinguish between intensity and plurality, Aranta: "Le redoublement (duplication) pour rendre la notion de pluralité est assez fréquent. Il sert à exprimer un degré d'intensité qui chez nous correspond à la fois aux

35. A. S. Gatschet, The Klamath Indians, Contributions to North-American Ethnology II, 1890 , p. 258 ff.

39) L. J. Frachtenherg, Coos, in F. Boas, Handbook of American Indian languages, II, 1922, p. 318 .

40) F. Boas, Kwakiut, Handbook of Amer. Ind. Lang. 1, 1911, p. 444.

41) I am indebted to Prof. Dr. J. L. Pierson for kindly completing and confirming my knowledge on the point. - Many grammars have overlooked the question and stop short at an insufficient ramark like this: "Auch durch Verdoppelung des Hauptwortes Kann dasselbe in den Plural gesetzt werden...." (examples: Menschen, Häuser oder Familien, Gewăsser) (A, Dirr, Gramm. der Annamitischen Sprache, p. 10). In a similar way Gray, o.c., p. $18 \mathrm{C}$.

4.) As Miss Dr H. Kohlbrugge (Yezd) informs me this phenomenon is much more frequent than H. Jensen, Neupersische Grammatik, 1931 says. 
formes de pluriel et aux formes de renforcement" ${ }^{43}$ ). Father Verheyen pointed out tbrit in Manggarai (Flores) agu toko ${ }^{2} n$ should rather be translated "his bones and all" than "with his bones"; although plurality vaguely presents itself to our mind, emphasis is primarily laid on the idea expressed.

The processes under discussion are also apt to express collectivity (whir:a often includes generality). In Sedik (one of the Formosan languages ${ }^{4}$ )) sédiq means "homo", sésé diq "people"; cp. Tag. kalá-kalakal" "merc'landise" (denoting several little or unimportant things as a collective; Jav. leluhur "ancestors": lwhur "high". The following are examples co'lleted from two non-IN languages of the Island of Halmaheira, where in is lin uited number of cases reduplicatives aesignate a group or a number of individuals or objects considered as a unity: Totelo o iòhaka "child": o nòha-nòhaka "a group of children", Tabaru nowaka "child": nowa-nowaka "offspring, descendants", and in a similar way terms for the elders, the g-own-ups of the village, the chiefs. We have already seen that Bol. M. "where are various mountains" may also mean "mountain-range". It should, in fact, be noticed that many duplicated IN substantives refer to objects or individuals which only or usually appear in groups, bodies or aggregations. The following are examples of words which only occur in duplicated form: Mal. juak "attendants, insignia-bearers"; kole $h^{2}$ "granular sweetmeats". Many collective names of animals which usually make their appeararce in swarms or flocks are formed in this way "6): Sasak ale "flyin:" white ants"; $a m a n^{2}$ "birds' lice"; Gajo ank $o^{2}$ "water-spiders". Hence such objects as fringe (Sas. $a m b u^{2}$ ), charcoal (Sas. arën ${ }^{2}$ ), husk etc. (Sas. eta ${ }^{78}$ beside eta?; Bis. $a^{2} a^{2}$ ), window-bars or trellis (Mal. kisi ${ }^{2}$ ), palisade (Ciajo $a_{a r m^{2}}$ ), merchandise (Bar. balu' ${ }^{2}$ ), dainties or refreshments (Sund. amperr etc. are often indicated by duplicatives, although in cognate languages the single noun may occu. In other cases a word can be more or less incidentally iterated to express the collective idea: Mal. gunun ${ }^{2}$ (beside gunun-ganain, the well-known type which we do not discuss here ${ }^{47}$ )) "mountains in general, mountain-range"; bara $\dot{n}^{2}$ "things of all sorts, impedimenta, goods"; borain: "thing, goods" (often logether with the suffix

43) A. Sommerfelt, La langue ta sociéte, Oslo 1938, p. 332.

44) See n. 88.

45) See E. Asai, Some observations on the Sedik language of Formosa, Philologi? Orientalis, I, 1934.

46) See above, p. 4

47) See Tijdschrift voor Ind. Taal, Land-en Volkenkunde 80 , p. 186 if. 
- con which itself may be a symbol of the same idea: Mal. tumbuh'an "things that grow, plants, crops"); Ment. bibilet "furniture".

With reference to a number of duplicutives I would venture to guess that they correspond to the pluralis extensivus of IE languages: as is weil known, the plural may express indefiniteness, extensiveness and summation: Eng. the high sees, the waters of the Nile, to extreme lengtis, Fr. les cieux; Skt. lokäh often = "heaven" or "world", äpadah "misfortune"; words denoting a coherent quantity or objects which constitute a mass like Skt. apah "water"; the plural of a people's name is, in Sanskrit, commonly used to designate the region inhabited by that people and in Latin Lucani is, as contrasted with Lucania, ancient and popular. I ask myself, if Jav. $a^{2}{ }^{2}$ "a large track of flat and uncultivated country" (cp. the Plains); alun "palace-grounds, royal esplanade"; Jav. Min. Mal. Sas. etc. awañ "airy interspace between earth and sky"; Sund. awat "vast and barren (of a track of land)" etc. may not admit of an analogical explanation.

Closely conrected with the idea of reiteration is reciprocity. In Sanskrit, where the type manus manum lavat is very common, the reciprocal pronouns are anyo'nya-, paras-para- and itaretara-. Reciprocal verbs designate repeated astion. Hence: Yami mi-palu "strike each oiher": puiz "to strike", Sediit mudodoi "grasp each other's hands": mudoi "to grasp". In Malay and other IN languages doubled word-bases with certain affixes express not only piurality of subject (agens), e.g. Mal, berr-lari" an "to run, running", but also reciprocity: ber-kasih"an "to love each other"; tikam-mén:kam "to fight with stah"ing weapons".

Repeated action easily becomes contin:ous or eyen customary action. In Sefik mubutubetaq means "to prick continually": mubetaq "to prick", in Yami ma-čita means "to search": čita "to see"; Bol. M. mo-babo" doman "carrying continually on the back"; morio-undo-undok "to frighten repeatedly"; Mal. têr-angok (of a ship) "pitching"; Jav, mlaku "io walk, loiter": mlaku "to go"; - so, these forms denote not only the objects serving as the instrument, but also the person who is repeatedly, usually or professionally engaged in acting, in practising an art etc.: Bol. M. mo-

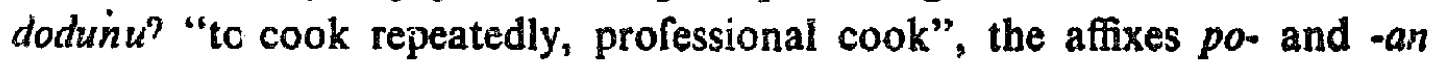
together with a reduplicated base express the idea "place where an action is regularly performed". A person always engaged in fetcning plates may be called in Toba Bat. si buwat" pingan. In Roti manalddo means "to grow thin", manaloliajo(n) "to grow thinner and thinner"; the same idca is expressed in Bol. Mal. by repeating the base after extending it with the 
prefix ko- : koropot-koropot "always increasing in strength". In a similat way the Takelma (Oregon) himimd means "to be accustomed to talk to" : himid "to talk to", Suaheli -ǐžekatžeka "to laugh continuously": -tžeka "to laugh".

As an extension of this use these processes often express a purely durative aspect. The action often extends over a period during which other thin can happen. Examples: Bar. mo-nan $u^{2}$ mampépé-pali "he was swimming whilst looking out ...."; Bol. M. ko-bulo ${ }^{2} i$ mobui mobuloi "while having a wife, (you) marry again"; raulohi (Amboit group of languages) lepa "to speak": lepa "to kcep speaking"; in Ngad'a this process forms words expressing "eine lang dauernde, ununte brochene Handlung ..., , $\mathrm{B}$. er redete und redete und konnte kein Ende finden" 48 ). Compare in modern Persian raft raft "he kept on walking". Hence Tont. ménainko-ñanko" "to keep crying"; Mal. di-ludah'-i-nya "he kept spitting", t: and waiting"; bër-lari " "to keep on running". Several words sppear persis" tently in this diplicated forn: Mal. mén-ěmbut " "to throb (as an artery)". This is, of course, especially the case with words expressing such ideas as resting, waiting, reflecting, being silent etc. Sometimcs the meaning of the duplicated form has become specialized to such a degree that we must transiate it by another term: Tont. ma-ali "to carry": ma-ali "to have about oneself, to be in possession of". Thus, IN can resort to this process in order to express a mood: Ach. mö-galu" "qo be in high spirits": gala" "glad"; Mal. berr-ménunin "to brood". In "rare's, duplication of words denoting characteristics of a region combined with the possessive suffix of the 3d pers. sg. makes expressions meaning "being always on the spot or in the tract of land indicated by the word-base", e.g. podo jaya nya da nululu "just follow the road"; Bol. M. monimbulu-buludanēe "to follow the mountain-range"; Roti ala ndjlb tasi-suikk- $a$ "they always go along the coast". Compare, in Nepali "(to walk) beside the river": khola kholä, in Mod. Greek (where duplication is a highly usual device) zia io yatis "going along the river". In many languages verbs can be duplicated to express a kind of durative or progressive action, «p., e.g. the Jap. nagarenagarete koko ni kitaru "wandering and wandering I have come hither" and such 'adverbial phrases' 49) as yukuyuku kun "he ents as he goes along", in Nufor (New Guinea) papp + an obligate-object means "to wash

48) Arndt, o.c., p. 37. See also H. N. Van der Tuuk, Tobasche Spraakkunst, 1867, \$175.

49) G. Sansom, An historical grammar of Japanese, 1946, p. 296. 
something", $p \vec{a} p^{2}$ "be wasbing, do the washing". Compare also the Skt. k.älakčlesu "in unirterrupted time", sthirva "standing (dur.)" and similar facts in orher languages. Of cource, this often applies to verbs expressing a sound: Toba Bat. peyok "(the hen) is cackling".

Although durative and intensive action may go together, Cassirer and other scholars are not right in entirely overlooking the emotionel root and the emotive aspect of linguistic repatition. From a psychological point of view Van Ginaeken ${ }^{51}$ ) argued that a new or startling event, that anythipg making a vivid impressior on our senses and any sudden and unexpected action, noise or appearance, in a word that any emotion may make us resort to linguistic iteration and duplication. Granting that various types of iteration, repetition of the same idea, 'abundance" (Abundanz) are often applied to be clear, to be unequivocally understood or to emphasize, we must, however, readily admit that emotion and excitement arge us to pronounce one or more words twice or even three or four times, and especially the words expressing the ideas which give rise to our emotion. As siveral scholars already had occasion to note ${ }^{52}$ ) this universal human disposition is at the root of various morphological, syntactical and stylistical phenomena: Lat. (Cicero) caeci, caeci, inquam, fuimus; abi abi; Engl. a big big man, the frequent type wishy-washy, Gr. qoßovipal xürorqérnouace etc. etc. Moreover, part of the popularity of these various and numerous repetitions must without doubt be ascribed to the satisfaction always felt in repeating the same muscular actions ${ }^{53}$ ) and to the acoustic pleasure of perceiving the sarne thythm. This rhythmical repetition aiso implies the highly appreciated devices of allizeration, rhyme and assonance ${ }^{54}$ ). These elements of speech may influence the system of language. In doing so they are, like all emotive processes, liable to depreciate or completely to lose their original force. Thus, in South African Dutch many duplications are admitted into the morphological system, where they come productive ${ }^{55}$ ): ' $n$ eie $e^{2}$ moeder "own mother".

so) See Van der Tuuk, o.c., p. 409.

51) J. van Ginneken, in: Leuvensche Bijdragen, 6 (1906), p. $288 \mathrm{ff}$.

52) See, e.g., J. Vendryes, Le langage, 1921, p. 180; J. B. Hofmann, Lateinische Umgangssprache2, 1936, 859 ff., 885 ff.; W. Havers, Handbuch der erklurenden Syntax, 1931 , p. 350 f. (6 139).

53) $C$. Jtspersen, Language, 1922, ch. V, 5 rigitly points out the importance of this point of view with regard to the well-known propensity of children to repeat words.

54) Corr pare, especially, Ch. Bally, Le langage ta vie, 1935, p. 105 ff; 130 fí.

35) See A. C. Bouman, Over reduplicatie en de woordsoorten, Nieuwe Taalgids 33 (1939; p. 337 ff. 
It is no wonder that IN often have recourse to emotive, intensive and other repetition (e.g. "malende Wiederholung") ${ }^{56}$ ): a Javanese merchantwoman may give rent to her amazement by saying: ambakna won nar̆an' "how is it possible! such haggling!" In Germanic languages we ofteu have recourse to o. dynamic accent. The emotional and emphatical aspect of duplication can still be clearly perceived in the so-called vetative turn, which is much in use in many IN languages: in Chamoro reduplication is an obligatory method in expres:ing the so-called 'prohibiting imperative': ca'miju săsaki "don't steal it". Cp. also Tont. vio'o maĕlě-ělěp pe "never drink toddy". In these languages this use of reduplicated forms is, however, so frequent that it has almost entirely lost its original force ${ }^{57}$ ). In Javanese negative sentences duplication may intensify the negation: ora lara" "not at all ill"; ora lali" "to forget it absolutely not", in Malay the intensive duplication is especially found after tidak or tiada "not" (gr. oi): dua puluh tahun mèreka tidak bĕr rsua lagi "as long as twenty years they did not meet": bèr-sua "to come near one another". In a similar way in KaroBatak la er-matê" "immortal": matē "dead"; la siran" ia "he did absolutely not part with ...." In other languages, e.g. Sangirese, reduplication is obligatory after any negative particle.

Now, many languages may express properties of objects which strike the mind, impress the senses and make powerful appeal to our emotions by ad ectival words formed after the processes under discussion. Words for colours ${ }^{68}$ ) and flavours, in a word, for impressions on the seuses ${ }^{59}$ ), such adjectives as big, strong, solid, round, wet are not seldom duplicatives or reduplicatives: Skt. sisira-"cold"; karkara- "hard, firm"; karkasa"rough"; (in Semitic languages adjectives denoting colours and infirmities are formed like the so-called elatives). In Mentawai we have ma-sesep "sour"; ma-kai" "sweet", in Javanese: mèteh "strikingly thick"; $k a p a h h^{2}$ "wet"; kénè h" "queer"; lundu "silly"; Sas. ampak "very many" (of animals or people); Mori (Celebes) bobotoli "round"; wewu" "troubled, muddy"; Mal. lelek ${ }^{2}$ "careless, slovenly". Elsewhere this practice especially appears when the adjective is emphasized ${ }^{60}$ ): compare such Malay sayings

56) I refer to B. J. Bijleveld, Herhalingsfiguren in het Maleisch, Javaansch en Soendassch, 1943, ch. I.

57) I refer to Schwarx-Alriani, Hoofdstukken uit de Spraakkunst van het Tontemboansch, 1908, p. 54. - As to Rotinese construc in see Jonker, o.c., p. 179.

58) I refer to Pott, o.c., p. $86 \mathrm{ff}$;; part of his examples are, of course, not to the point or incorrect. Cp. also H. Jensen, Der steigernde Vergleich, Indog. Forsch. 52, $108 \mathrm{f}$.

59) We must, however, also reckon with the iterative aspect.

60) 1 lso refer to C. Lopez, Reduplication in Fagalog, p. $24 \mathrm{f}$. 
as bodoh" sépat nak makan pancin mas "stupid as a sprat that swallows a golden hook". Or we may find it with a limited number of words denoting such concepts as "alone; by oneself" (Bim. kèse ; Mal. sě-ora $\dot{n}^{2}$ beside sě-orañ); Tag. muntī "small" makes an intensive form mumuntī which is, however, as a rule used as a plural like the reduplicated forms of other words meaning "few, little" ${ }^{\text {or }}$ ). It may be noticed in passing that in Tabaru (Halmaheira) repsated and reduplicated adjectives, besides denoting a high degree, serve as attributes.

There even exist languages where any 'adjectival idea' tends to be expressed by such f.rms. In some Celebes idioms (Buli, Leboni) reduplication seems to be the isual manner in forming this class of words. In Banggai a considerable number of adjectives is reduplicated: babasal "big"; bebelay "broad"; bobosul "satisfied", bobonkos "stinking"; bobonol "dull of hearing". As in most cases the (unreduplicated) word-base does not occur, I am under the impression that these words, which often convey one of the above-mentioned meanings, constitute a more or less petrified group.

Often, however, these prosesses are especially found when the adjective denotes a high degree of the quality expressed by the single word. Thus, in Hindi a repeated adjective is intensive in force: "very little, very green etc."; this also includes exactitule: bātika ke bic ${ }^{2}$ mem "in the very middle of the garden". Cp. also Nepali sin $\bar{a}^{2}$ bastu "very small things" and Sanskrit alpālpa- "very small". In a similar way Iloko (Philippine Islands) dakes ${ }^{2}$ means "ah! how bad". In Italian ard Roumanian "le redoublement, c. à d. le répétition d'un seul et même mot tst une manière de renforcer l'idée ${ }^{62}$ ): It. I' faccione diventi amabile, il vocione dolce ${ }^{2}$; Roum. un codru mare "une grande forêt" ". In other Romance languages apart from dialects, this phenomenon is only occasionally found: Fr. il est gros ${ }^{2} ; \mathrm{cp}$. Germ. ein alter ${ }^{2}$ Mann; Eng. goody-goody beside goody. In these cases the emctive force is often clear. Modirn Greek has recourse to this device to emphasize the

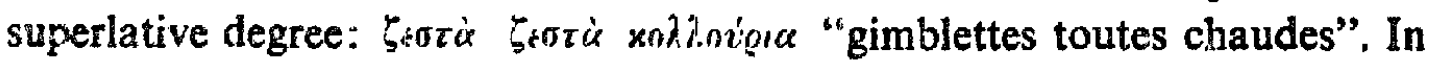
Semitic languages this process is well known: Arab.'abinun" "very proud"; Eth. Sannaịt ${ }^{2}$ "die allerschönste". Thus, Sedik has bubalaì or bulbalaĩ "very truly": balai "truly", cuk cekka "just middle": cekka "middle"; Yami pipija "very good": pija "good"; lalaku "gigantic": laku "big"; Banggai lapa" "quite good"; turu "quite true"; Masarete (Buru) gòsgòsa "very nice";

61) F. A. Blake, A grammar of the Tagálog language, 1925, 32 (where the author speaks of "indefinites") and 53 (where he calls it intensive forms).

62) W. Mayer-Libke, Grammaire des langues romanes, III Syntaxe, 1900, p. $164 \mathrm{f}$. 
Bima na-taho" "very good". In Bol. M. repetition of an adjective may indicate a comparatively high degree: "this house is better (mo-pia) than that" (《 "as compared with that house"). In Malay perntiñ ${ }^{2}$ may mean "very important": pentin "important"; luka "wounded (when many parts of the body are cut or torn)": luka "wounded"; mésin těrban itu naik tingi "the aeroplane rose to a great height"; lemma ${ }^{2}$ badannya, hampir ia akan mati "he is very weak and on the verge of death"; in Modern Malay pémbunuhan bésaran means "murdering on a large scale". Some types of duplication, like besaran, have analogically extended in a short time and are apt to constitute form classes corresponding to elative and superlative categories in Western languages: istana itu sě-běsar'nya "the palace was largest of all"; sĕ-baik'nya "as well as possible".

In Chamoro and other IN languages the same form of reduplication denotes, when applied to an adjective, a high degree (sometimes called a "superlative') when applied to a verb, intensity: cãgogo? "very far": cago" "far"; juttete" "throw away (the whole of a thing)": jute? "throw away". It needs no comment that intensive action is often expressed in this way

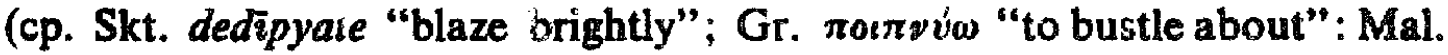

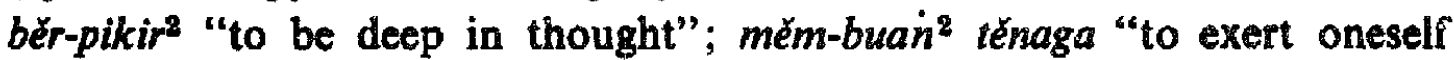
to the utmost"; Tag. pag-puputul-in "shall, will be cut intensively". C.p. also such words as Mal. mati"an "(fighting) to the death". A mere note must suffice with regard to the interesting doubled or reduplicated substantives: Bar. pale ${ }^{\mathbf{2}} m u$ "your own hands"; ri yoyo"nya "on the very top", the Rotinese construction enok-a tane "the path is nothing but mud". In the Manggarai mala kéta tauns wima" agu ana $a^{2} k n$ "they are all dead, his wife (wina $a^{2}$, although he had only one wife) and his children" the duplication expresses totality; cp. also Bim. iawili-wili-na "the whole of her breast".

There is a striking tendency in many IN languages to use the same processes when a diminution of the original meaning is intended. Substantives then have the force of our diminutives: Day, kararahak and karaharahak "kleiner Rest, Restchen" (3)): karahak "rest"; kakabar and kabakabar "ein wenig Nachricht": kabar "news". "Gern gebraucht der Dajack solche Diminutiva in Verbindung mit jaton "nicht", makin dia "selbst nicht": jaton taio gawie "er arbeitet gar nicht (er hat durchaus kein Werk)". Bug. bola "a little house": bola "house", etc. In Tagalog, the suffix -an

63) See also A. Hardeland, Versuch einer Grammatik der Dajackschen Sprache, Amsterdam 1858, p. 73 . 
with fully duplicated roots forms diminutives: ibonibonan "little bird": tbon "bird".

It is, however, not always easy to render the exact meaning of theic forms in English. Courtesy and modesty often have a hand in the matter. Sometimes the repetition of one of the important words is a sign of hesitation: the person speaking has not succeeded in performing a task, he does not venture to speak his mind or wants his partner to be under the impression that some object of his own is of little value ${ }^{4}$ ). Adjectives of this type appear with great frequency. They can often be translated by "rather -": "bei Verben und Adjektiven ersetzt die Reduplikation unsere $\lambda$ dverbien "zitemlich, recht, etwas, nicht un-", drückt also geringes oder nicht sehr hohes Mass aus" 35): mămawleg "nicht gerade schlecht": mawleg "gut". Cp. Tont. lewo-lewo'oka "more or less weak" 6e); Bol. M. moongo-ongot "rather long"; Mori teku"da "somewhat angry"; Day. sa(na)sanan "ziemlich ¿uhig, oder: ganz ruhig", Mal. baik ${ }^{2}$ juga (and other phrases with juga "all the same, in a way, not very"; sakit juga "not very sick") "tolerably good, well". In other cases we may translate these adjectives by Dutch words in achtig or -elijk: Mal, putih" "somewhat white, whitish"; Mac. kwoyj" "yellowish" (they serve in general to indicate colours for which there is no exact term). The sense is, of course, often not clear apart from the context and from modulation: thus, the Roti pila may mean "reddish" or "very red". A concept like "ailing, of weak health" is expressed in this way: Roti hedi"; Bol. M. motaki-takif; Tont. rawo-rawoi. One single example may suffice to remind the reader of a similar use of diminutives in other languages: Ital. azzurricio "somewhat blue". As to itetation cp., e.g., in Sanskrit ksämaksāma- "rather thin". Verbs dexived from duplicated bases have sometimes a clearly diminuive meaning, so as to express "a little", or "to be something like....": Tag. mag-bagyo" "to be something like a hurricane"; Mac. kincá "to curve": pa-kincá-kincák-i "to bend the fingers a little"; Roti tobi" "to be somewhat warm": tobi "scorch" (sometimes, indeed, a degree of diminution or reduction is indicated); Bim. ka-rana "heat it a little": Mal. datan' ${ }^{2}$ juga añ in bĕrtiup "a light wind began gently to blow". A mere note may suffice here with reference to the restrictive meaning of the type Tag. asin-asin "salt only" and to such restrictive numerals as the Tag. dadalawd "only two"; cp.

4) I also refer to Esser, Klank- en vormleer vain het Morisch, 1, p. 77, no. 1 .

65) Costenoble, o. c., p. 139.

66) Schwarz-Adriani, o.c.: "gnin of meer, tamelik wel, nogal...." 
also pipiso or pipisopiso "only one peso". In the same language repeated pronouns may have a similar meaning, i.e. a specification, limitation or restriction: "If it were only I, and I only (aku-akó), to whom he had spoken ..." 66a)

Those authors who seem to have derived this function from the meaning "being similar, to represent oneself as" are, in my opinion, in the wrong ${ }^{67}$ ); it is, as far as I can see, very closely connected with the preceding function. In both functions, the augmentative and the limitative, these processes make forms indicating that an action or process takes place or that a nominal concept is present to some degree. Sometimes this means: to a comparatively high degree, sometimes, however, the contex ${ }^{*}$ and the circumstances show that a low degree is meant. We may compare the IE so-called comparative in jes-/ios-/is- (Lat. melior), which originally was an adjective pointing out that a person or an object possessed a certain quality or property to a particular degree. We had better call it an intensive: cp., e.g., Skt. alpüyasī kālena "in course of (after) a rather short time,

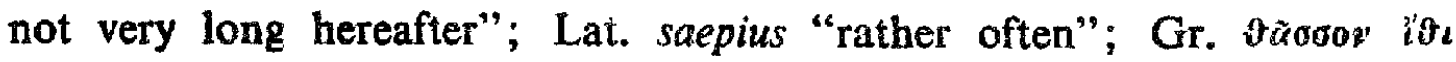
"go as soon as possible". And in the IE languages the so-called comparative has retained these functions. Those scholars who spoke of "carelessness in the employment of comparative and superlative" and who believed that a person or thing compared with is either always expressed or implied, have often been mistaken. In popular speech a comparative is often preferred instesd of a superlative, because it shows the spertiter's modesty, courtesy or indulgence and his aversion to exaggeration and strong expressions. Thus, we find a "weakened comparative" ${ }^{8}$ ), or, racher, "sbschwächende Komparativ" ") in Dutch heer van rijper leeftiji; Germ. ein alterer Herr; Eng. the weaker sex (but the fair sex), and other such well-known examples.

These comparatives used without implying a comparison are sometimes liked because their meaning is general and indefinite. The same may be said of such duplicated words as Jav. tul:u "buy": têtuku "to buy something, or to buy in general"; Mad. paparen "pny gift"; Sund. lölompan-an "to travel about"; cp, also Bim. $a u^{2}$, llial. apa " "iny (whatever)"; Tont. ambisa-wisa "anywhere": ambisa "where"; Ma!, buah"an "fruits of all

66) See Lopez, o.c., p. 144.

67) See e.g., H. J. E. Tendeloo, Maleische gramn, atica, 1, Leiden 1901, p. 95 and J. H. Neumann Schets der Karo-Bataksche spraakkunst, 1:22. \$ 148; D. Gerth van Wijk, Spraakleer der Maleische taal, 1909, \&258.

68) Jesperse1, The philosophy of grammar, 17. 248.

69) W. Havirs, Handbuch der erklärenden Syntax, Heidelberg 193!, p. 187. 
sorts". CF., in Sanskrit, yo yah "whosoever"; in Hindi kabhi" "sometimes" etc.; Lat. quisquis.

In Stmitic languages duplication is very popular as a means to express diminution and contempt: Arab. su'rür "poetaster"; baina "betwixt and between". The well-known type wishy-washy is often clearly contemptuous; in Sanskrit, an intensive form like lolupyate came to mean "he breaks in a wrong manner". As compared with the base-word, Karo-Batak duplicatives often have a contemptuous meaning: tawa "to flirt": tawa "to laugh"; najar"i "to talk a person round": najar-i "to teach"; cp., in Toba-Bat., bosi" "refuse iron": bosi "iron"; Mad. balandha "Dutchman" dhaq-balandhaq-ain (the same, but contemptuously).

The 'diminutiv' and indefinite force is, in my opinion, at the root of the well-known type (Mal.) kuda "trestle" (: kuda "horse") which, generally speaking, denotes similarity. As Toba-Bat. bosi" means "iron that is no real iron", so a dalan" is "a path that is not a real path (dalan)", i.t. "a path which is not in daily use". Cp., in Tagalog, anák $k^{2}$ an "an adopted child". Sometimes the repetition betrays the speaker's embarrassment, he hesitates to give a thing a name and provisionally calls it "something like ...."It is a general practice with Indonesians to indicate a thing similar to the thing meant by the wordbase in this way: Karo-Bat. nip $\bar{e}^{-2}$ "caterpillar": nipe "serpent"; Ment. luga "fins" of a fish which are, as it were, its oars (luga)"; Jav, jala" "net-work, trellis-work": jala "casting-net"; putih" "something giving the impression of whiteness": putih "white"; cp. also winih "seed": wiwinih "origin"; bantèn "wild ox": bèbantèn "champion"; MaJ. ran-jharanan is anything suggesting a horse (image, statue, drawing); Mal. kuda means "trestle, bridge of violin, wooden yoke in Malay loom, roof-trusses, clothes-horse etc." In conventional standard Malay instances are rather limited (cp. also ular" "pernon": ular "serpent"), but in colluquial speech they are not seldom used. In Toba-Bat. we find doubled substantives denoting objects which are primarily characterized by the idea expressed by the base-word, this base being an unduplicated "qualifying verb" "9): poso "cub, young child": poso "to be young". When, however, preceded by the emphasizing article na these woras are adjectival: na rata "(things that are) greenish". In many languages this type is much in use to form names of plants and animals (see above); often, however, the semantic connection is not clear. A special meaning appears

70) H. N. Vaa der Tuuk, Tobasche Spraakkunst, II, Amsterdam 1867, p. 404. 
in the Oirata peepele "toy-bow": pël<Dutch pijl "arrow"; Yami avain' "toy-boat"; Bontoc asasu "a toy-dog made of clay": ass "dog". With verbs this type may indicate playful performance of an activity: K. Bat. erdakan "to boil rice": erdakan" (of children) "play boiling rice", a shade of meaning also found in Kwakiutl etc. (In Dutch diminutives are popular: schooltje spelen "to play school". In other cases the word means "to convey the impression that one is -": Day. bawol "hog": bawobawoi, babawoi "to be (always) like a hog". Unreality is expressed by the Day. lalikä "to be as it wer mu 1" (e.g. of a drawing which is not distinctly visible). by the Toba-Bat. hardul" "to convey the impression that one is sitting"; modom" "to lie down as if one is sleeping": podom "to sleep". Here may belong at ledst part of the verbs connotating the idea of "trying": TobaBat. mar-dalan "to try to waik" (of a young child).

Part of the words of this type tend to be used as more or less characterizing determinatives. Thus, in Madurese binè means "vife" and lakè "husband", but òren ("man, human being") bibineq and oren lalakeq respectively mean "a female or male human being". The Sundarese word for "kusband", sa-laki, is a derivative, the single base-word lakl is only sound in compounds and in metaphorical use ("pestle"), laiaki expresses the concepts "man, masculine, male" (and even: "manly"). Whereas in Toba-Bat. the single base added to a term of relationship in Jicates sex and . olit $^{2}$ means "a youth" or "a bachelor", the Malay laki $i^{2}$ (lak, "husband") cuvers our "male, mas. culine, manly". In Javan'se isih bocuh" means "his is still quite a boy"; the Nias ono (ono "child") denotes "still young", the Day. hahuma (huma "house") "looking like a house".

Duplications are, in fact, often instrumental in forming adjectives (see above) or, generally speaking, in transposing a concept in another category of words. The Rotinese not only say $f u ! a^{2}$ "to become (or to be) somewhat white", but also lasi" "to be very old"; in the first case there is an acj. fulak "white" and a word fula "to become (or to be) white", in the other case only lasik "old" exists. Paulohi reduplicatives form verbs from substantives: tai "dirt": tatai "to be dirty". Compare, in Javanese, ikezt "to tie up a person's head": ikert "head-band"; obor" "to cook on a fire": obor "torch"; $a$ in in "take the air": anin "wind". In other cases we find a Rotinese single word, being a transitive verb, beside a duplicative expressing the intransitive idea: ingali "strew": ingali "scattered, spread". Jonker ${ }^{11}$ ) suggested that these intransitives are, for the greater part, a

i) Jonker, Rottineesche Spraakkunst, p. 213 (cf. p. 190). 
product of analogy: originally, he thirks, a few very common intransitive verbs were duplicated. Another function is illustrated in the same language, in which reduplication and doubling are used to derive causative verbs: papake "to dress": pake "to wear". In Hottentot and other African languages causative duplications are frequent.

Most interesting, however, are the duplicatives serving as adverbs, a category which has been insufficiently noticed by the authors of most grammars. Compare, for irstance, Mal. pagi "early in the day": pagi "morning"; lama "after some length": lama "length (of time)"; tiba" "suddenly": tiba "to arrive suddenly"; diam" "on the quiet etc.": diam "quiet, silent" etc. We have often to do with standing phrases. In Javanese we find, e.g., suwe $e^{2}=\mathrm{Mal}$. lama ${ }^{2}$; in Achehnese phōn" "formerly": phón "beginning"; in Paulohi wolo "well": wolo "to be good" etc. etc.

Many IEadverbs are only stereotyped cases of substantives or adjectives: Lat. meritō $>$ meritō "justly" is eviciently an old ablative, Skt. $\bar{\imath} l a y \bar{a}$ "jokingly", añjasī "quickly" and numerous other instances are instrumentals either distinctly felt as such or petrified. Like daily parlance and the artless speech of the common people, the ancient IE languages often resorted to other expressions where most modern languages would prefer to put an adverb. Thes 2 expressions were, as a rule, added when the person speaking wanted to lay stress on the idea conveyed by the verb: Lat. vitam vivere; Skt. ucchrayasva dyaur iva "rise uplike the sky", when he wished to dwe'l upon the attending circumstances: Skt. unmatta iva "like a madman", or to give vent to his emotions: (Skt.) as a father to his sons, i.e. carefully; Eng. thank me no thanks ${ }^{72}$ ). Like these other methods applied, adverbs express the individual character of an action or a pror sss (degree, intensity, time, place, attending circumstances etc.): Eng. he sin's delightfully, he looked wistfully; he grew' richer and richer, he answered with impatience. "L'adverbe est le support de l'ćlément subjectif de la pensée, et l'intonation variable is charge d'exprimer la dose de sentiment qui l'accompagne" 73): it may express appreciation, interest, individual judgment etc. etc. ${ }^{74}$ ).

Hence, adverbs and expressions doing their duty may easily suffer from such tendencies as cumulation, substitution and other processes which

72) See my Stilistische Studie over Atharvaveda I-VII, Wageningen 1938, p. 66 and my Remãks on Similes in 3anskrit Literature, Leiden 1949, 15 . I also refer to M. Deutschbein, Neu-englische Stilistik, Laipzig 1932, \& 69 en 71 .

73) Ch. Bally, Traité de stylistique francaise, 12, p. 330 .

74) I was not able to consult H. Gauger, Das Adverb als Gefuhlsträger in Englischen und Deutschen, Diss. Tubingen 1923 (Maschinenschrift). 
are apt to occur in emotional speech or individual style: Lat. ergo igitur, una simul, cupide studere ("Abundanz'); "very", "extremely" etc. are liable to lost their emotional and intensive connotation and are easily replaced by "awfully". So, many words which now are adverbs or adverbial phrases originally were emotive-intensive elements and in many a case they still possess this character. It is, therefore, only quite natural that doubling and reduplication have much to do with the formation of this category of words. Such Sanskrit adverbs as sanaih" "gradually, quietly"; punah"

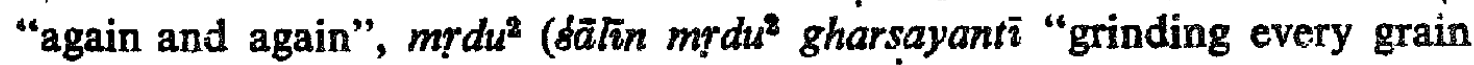
of rice to pieces" or "grinding intensively, well") often display their original iterative or intensive connotations. In Modern Persian, where most duplicated adverbs are derived from substantives, we find e.g. mur-mīâna "slowly": mür "ant". Cp. Hittite karsikarsiyaz "in very truth": Karsis

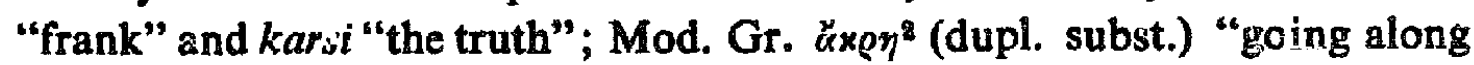
the coast". Japanese and Turkish nouns can be reduplicated to form adverbs: Jap. nakanaka "certainly"; Turk. dilim" kesmek "to cut to slices". In Sudanese languages this type is most common: Ewe zo báfobafo "beschreibt den Gang eines kleinen Menschen, dessen Körpertiile sich beim Gehen lebhaft bewegen" ${ }^{75}$ ). In Tabaru we find o wan $e^{2}$ "in the day-time": wane "day, sun". The individual, occasional and emotional character or origin of these expressions is often evident (mind the frequent repetitions in South African Dutch, e.g. die bal rol net ${ }^{2}$ oor tie dwarspaal, Ital. avoicinare adagio $^{2}$ ), but elsewhere "le reduublement, indejendamment de sa valeur expressive, est lui-même un procédé de tra'ısposition" ${ }^{76}$ ).

In IN languages, too, this character is s's evident that in many of them all iterated words, doing duty as adverbs, are, as a rule, intensive, iterative or emotive. Cp.: Tont. ure "quite a long time": ure "long"; Màsarète rèsrès $k$ "quite certain, very well". In Tagalog and other languages of th: northern group duplicatives generally convey an intensified meaning; in Macassar scveral adverbs are formed by duplicating a substantive which expresses, in this case, repetition, continuance or indefiniteness. In Banggai which does not make much use of adverbs, dampas moso-mosobit means "go very rapidly". Elsewhere such duplicatives are usually preceded by the prohibitivm particle (see above, p. 185): Jav. aja lunia adoh" "don't go too far here they express excessiveness). An originally intensive or

75) D. Westermann, Grammatik der Ewe-Sprache, Berlin 1907, p. 83.

76) R. Godel, Formes et emplois du redoublement en turc et on armenien moderne, Cahiers Ferd. de Saussure, 5, y. 10. 
emotive connoiation may often been discerned in such Malay and Javanese terms as Mal. pagi "carly in the morning": malam" "late at night"; laun" hari "long ago"; $d$, , ıganya baik " "l,e was thoroughly (or duly) vigilant": baik" "good, well"; Jav. daja "as quick as possible"; těmèn" "truly". This is especially clear in many words belonging to the rather numerous group of duplicative adverbs, beside which the same language does not, at present, possess the single word: Mal. (Kelantan) lolor "quickly; at once"; pala" "out-and-out, quite"; (Batav.) lapat" "faintly visible or audible". In derivatives like Jav. kuminter-pinter "pretend to be very clever (pintěr)" etc.; Mal. sé-baik"-nya "as well as possible"; in stereotyped phrases like Mal. baru ${ }^{2}$ ini "just this minute", in duplicatives formed with the possessive suffix -nya etc.: Jav. kèh ${ }^{2} \dot{e}$ "at most", Sund. geedèna "at the very most" this function has developed more or less productive regular grammatical categories. Among the characteristics of the IN family of languages is the liability of many verbs to adverbal functions: both verbs complement each other or the second qualifies the former. In this case iterated forms are by no means exceptional. Whereas the Mal. ayerr bërondak" means "the vater is in commotion" (bër-o. predicate), kapal bĕrlayar bér-ming "2 means "a vessel sailing close to shore" (complemental concepts); cp. orainlah datan berr-duyun" "people came crowding (or: in crowds)". Compare also hidup "living; being alive", but lapah hidup" "flayed alive', such Javanese instances like matur bisik" "to speak in a whisper" (or: "to whisper"), and Rotinese phrases (which are, however, also found in other IN languages) like ana laök $b i^{2}$ "he goes whilst being afraid" ( $b i$ "to fear").

So, it is no wonder that in Bare'e doubling and reduplication are characteristic of adverbs in general: naso'o mainti" "he was bound tightly". "7) It goes without saying that often the exact connotations of a given form

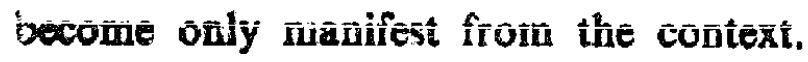

It is perhaps unnecessary to point out that the processes under discussion can also derive substantives from single words without explicitly substantival meaning. According to Jonker ${ }^{78}$ ) there are no Bimanese instances, but in Rotinese verbal substantives derived from duplicated verbs (or, rather from bases, from which also duplicated verbs are derived) are, as a rule, seduplicatives; in compounds and standing phrases a single verbal sub-

7 ) As to Dayak I refer to Hardeland, 0.c., p. $72 \mathrm{f}$; $140 \mathrm{ff}$.

ri) Jonker, Bimaneesche Spraakkunst, p. 218. 
stantive occurs, - the ancient use, as Jonker judges, who unconvincingly holds ${ }^{79}$ ) that these substantives, in general, are built up on the pattern of the instrument names (see above). Compare, besides, Bug. anä " $^{2}$ "hurdle": anän "to plait, braid"; Cham. si?ug "to beat with the back of a knife (sisi"ug)". In Tagalog, the underlying form tawa "a laugh" appears reduplicated in tatawa "one who will laugh", in Javanese dëmit means "in secret", dëdémit "a non-human being".

I now come to an interesting point. As is well known, speechforms that are homonymous with tabu-words are disfavoured, and homonymy, in general, when leading to ambizuity or misunderstanding, can result in disuse or alteration of a form. Esser ${ }^{80}$ ) already surmised that the Mori sele "striped cloth", which is, etymologically, the Bug. cele?, has become a geminated form because sele means "vagina". Besides, when a word is used with considerable frequency, and especially, if it has tecome polysemantic, speakers may feel obliged to substitue for it sorse cognate term of more exact and specific meaning. Then, special forms or doublets may be made subservient to express a special meaning or processes which are a living force in the language may come into operation to create a doublet conveying a specific meaning. In Malay labu means "gourd" and "gourdshaped, so-called calabash water-vessel"; such a vessel being made of coconut-shell may be called a labu kérambil (Min.; kérambil "coconut"); it may be made of earthenware and callec' lis u tanah, labu batu etc. (lanah "earth", batu "stone"); as contrasted with a "gourd" (labu) a "calatash water-vessel" is indicated by labu ayerr (ayeer "water"), labu" or lélubu. Thus a doubled or red uplicated form is useful 10 express a spocial meaning: Roti delu "to beat or strike, in general": dede " "to strike a gong; to knock at the door". Thus, in "Tonternboan, Bolaang Mongondow and other languages very minute semantic distinctions may be expressed by such doublets as Bol. M. kobaya-baya" "to be walking (of a person who is continually engaged in walking and travelling)": koba-kobaya" "to be walking (of a person going about)". Jonker ${ }^{81}$ ) pointed out that in Rotinese i.ot sniy. from verbal, but also from adjectival base-words reduplication derives substantives: nanaluk "length"; now and then, however, the reduplicated form is used to make a distinction between two shades of meaning. e.

79) Jonker, Rottineesche Spraakkunst, p. 213; see aiso p. 199 ff.

20) Esser, o. c., I, p. So.

81) Jonker, Rottineesche Spraakkunst. p. 208: (p. also f. (19). 
matak "underdone": mamatak "uncooked". Compare, in the same language: ndolo $-t$ obj. "to pass along": ndolo "to follow (the coast etc.)": ndond8lo "to go about for inspection." The Bim. kani means "to wear (an article of dress), to use (something)", kani "to put on, to clothe oneself with ...." Even in those cases where the original function of the process is perfectly clear, its actual function is often in the first place to be helpful in making "emantic distinctions. Compare, e.g., the Jav. ilat" "a thing shaped, approximately, like a tongue, e.g. the tongue of a buckle", Dutch tongetje): ilat "tongue" (Dutch tong); Bug. manu" "bird": manu "fowl, ben"; Mal. muka "forced looks of friendliness": muka "face" 82), In Toba Batak duplication is sometimes subservient to form words indicating 'special deeds' i.e. crimes: bunu" jolan "manslaughter": mamunu (base burn) "to kill".

It is clear from what precedes that there are many words which only occur in doubled or reduplicated forms. Although we are often able to account for it, our inability will prove to be great, when we wish to find out the underlying motives and the operating forces which have urged one language to prefer reduplication to indicate, e.g., instrument names, while the other chose another method for that purpose. All facts that may give evidence as to the history of the phen umenon and the extension of the forms under discussion should, therefore, be welcoined. De Josselin de Jong ${ }^{83}$ ) recently pointed out that in Erai (Wetar) reduplicated forms may be translated by "who is -, being -"; in many cases. however, their function is to emphasize the idea they express. But it would seem, this author adds, that in most cases forms with or wi hout a prefix may be used at will and occasionally the latter are apparently becoming obsolete: musun "emipty", but mamusun is more common ${ }^{84}$ ). In a similar way, we find in Sundanese, which is very fond of reduplication, beside the far less urual tamu "guest", the synonym tatamu; Javanese, which is nearly related to Sundanese, always has tamu. This point and other questions in this connection should be thoroughly investigated in a large number of IN languages.

Space forbids to dwell upon an emotive-stylistic function of duplicated

8) I also refer to Jonker, Rottineesche Spraakkunst, p. 181

83) J. P. B de Josselin de Jong, Studies in Indonesian culture, II, 1947, p. 91.

54) See also Jonker, Rottineesche Spraakkunst, p. 187 and Van der Tuuk, o.c., p. 403 f.

85) See e.g., Havers, 0.5., p. 113; Deutschbein, System der neuenglischen Syntax, 1917, p. $192 \mathrm{ff}$. 
words which is in many respects reminiscent of the IE type (Lat.) o stulte stulte. For the same reason a mere note must suffice with reference to a 'syntactical' function. Kiliaan $\left.{ }^{86}\right)$, who was a master of nonsensical interpretation, held that in Javanese duplication "may do duty for a concessive clause" and tried to account for that supposed fact in a complicated and totally unconvincing argument. Father Aindt ${ }^{87}$ ) pointed out that in Ngad'a repetition of the verb may express "verschiedene konjunktionale Verhältnisse". Now, in the Javanese sentence merntah" iya dipanan "though they are unripe, he eats them" and in similar sentences having a duplicated verb-form in Ngad'a (and other IN languages) the predicate has been emphasized by the process of doubling: "unripe.... he eats them" $>$ "they are unripe, it is true, yet he eats them". Likewise, the Jav. sinau ${ }^{2}$ yèn dipeksa means: "he learns, if we (they) force him", i.e. "he does not learn unless we force him". In Baré'e nawutu penainya, be ma*i meuns: "he dréw his sword (or: "he tried to draw his sword, see above, p. 177), but it did not come out", which may be translated: "although he drew ...". Father Verheyen, the author of a copious paper on reduplication in Manggarai ${ }^{88}$ ), correctly remarks that a sentence like cai ${ }^{2} s$ isé oné golo hitu poka lisé ca haju" they cáme to the hill (i.e. "as soon as they came....), they cut down a tree" consists of two coordinated clauses. He rightly says that even without duplication in the original Manggarai a concessive conjunction might be used in a translat on : énot ngo'o liha .... "he gazed... (although he gazed...) he did not ste anything", while $e^{2} o^{2}$ ingo'o lihti etc. might be translated: "he gazed and gazed .... (, although he gazed . .) etc." As soon as I can find an opportunity, Intend to return to this point. ${ }^{99}$ )

Van Limburg Stirumstraat 17

J. GONDA.

Utrecht (The Netherlands)

86) H. N. Kiliaan, Javaansche Spraakkunst, 1919, p. 278.

87) Arndt, o.c., p. 37 f.

88) J. Verheyen, Woordherhaling in het Manggarais. The author kindly sent me a copy of his $r$ anuscript, which now has be printed in the Tijdschrift voor Indische Taal-, Land- en Voikenkunde, Batavia (vol. 72, p. 258 ff.).

89) Abbreviations: Ach. = Achchnese (Sumatra), Bar. = Bare'e (Celebes), Bat. = Batak (Sum.), Bim. = Bima or Bimanese, Bis. =- Bisaya (Philippine Islands), Bol. M. = Bolaang Mongondow (Cel.), Bug. = Bugi or Buginese (Cel.), Cham. = Chamorro, Day. = Dayak (Borneo). Jav. = Javanese, Mac. = Macassar (Cel.), Mad. = Madurese Mal. $=$ Malay, Ment. = Mentaway, Min. = Minangkabau (Sum.), Ng. Day. = Ngaju
Dayak (Borneo), Sas. = Sasak (Lombok), Sund. = Sundanese (Java), Tag. = Tagalog (Phil.), Tont. = Tontemboan (Cel.). 